\title{
Politika és média - A magyar médiahálózat szerkezete 2018 őszén ${ }^{1}$
}

\author{
FARKAS ATTILA ${ }^{2}$
}

\begin{abstract}
ABSZTRAKT
A tanulmányban a magyar médiavilágot elemzem, három 2018 ôszén megjelent politikai ügy kapcsán. Az Orbán-Simicska-konfliktust követően jelentős változások történtek a médiavilágban. Több új médiumot ekkor alapítottak meg a Fideszhez informálisan kapcsolódó üzletemberek, miközben más médiumok hirtelen gyorsasággal megszűntek. 2018 öszére a Simicskabirodalom lényegében felmorzsolódott. Ezzel ellentétben a Fideszhez informálisan kapcsolódó médiumok száma megugrott. Hipotézisem szerint az átalakulás következtében a magyar médiavilág továbbra is polarizált képet mutat. Az őszi ügyeket háromféle módszerrel vizsgáltam. Elöször a leíró statisztika elemzéséből kiderült, hogy a kormánypárti és nem kormánypárti médiumok napirendje jelentős eltérést mutat. Másodszor az egyes ügyekben megjelent tudósításokat szisztematikus tartalomelemzésnek vetettem alá, amelynek eredménye azt mutatja, hogy a két csoport tartalmi értelemben polarizált. Végül a médiumok egymás közötti interakciói révén hálózatokat hoztam létre. Ellentétben az első két módszerrel a hálózatelemzés nem erôsítette meg a polarizáció tézisét.
\end{abstract}

KULCSSZAVAK: médiarendszer, médiavilág, polarizáció, tartalomelemzés, hálózatelemzés, Fidesz, empirikus kutatás

\section{ABSTRACT}

\section{Politics and Media - The Hungarian Media Sphere in the fall of 2018}

This article focusing on the changes within the Hungarian media sphere after the OrbanSimicska conflict. After the conflict the Hungarian media sphere has changed radically. Those of the media outlets which belonged to Lajos Simicska had cease their operation. Business persons who have close ties to Fidesz has founded new media outlets. In my article I analyzed three political case which happened during the Fall 2018. I assumed that the media sphere in Hungary had become more polarized than before. In order to prove it, I created two groups of the media outlets. The first one, which have close ties to the governing party, and the second one which has not got ties to Fidesz. During my research I used three different methods. First, I recorded a

\footnotetext{
${ }^{1}$ Szeretnék köszönetet mondani Bene Mártonnak a tanulmányhoz füzött értékes hozzászólásaiért és Burai Krisztinának az adatok felvételében nyújtott segítségéért. Készült az Emberi Erőforrások Minisztériuma Új Nemzeti Kiválóság Programjának támogatásával.

${ }^{2}$ PhD-hallgató Eötvös Loránd Tudományegyetem Politikatudományi Intézet.

Elérhetőség: attila.farkas.02@gmail.com
} 


\section{KÖZELKÉP}

statistics about the articles. According to this, the media agenda shows large difference between the groups. I did content analysis on the articles, which shows us a huge polarization between the groups. The third one, was network analysis. The network analysis did not confirmed the polarization hypothesis.

KEYWORDS: media system, polarization, content analysis, network analysis, Fidesz, empirical research

\section{Bevezetés}

A magyar médiavilágot a kutatók nagy alapossággal vizsgálták az elmúlt évek során. A 2010-es kritikus választás után (Enyedi - Benoit 2011) a Fidesz szinte azonnal hozzálátott a magyar politikai rendszer átalakításához, amelyből a média, a médiát szabályozó törvények sem maradtak ki. Bajomi-Lázár Péter tanulmányában egy új korszakként nevezi meg a 2010-től eltelt időszakot napjainkig (Bajomi-Lázár 2019), amely korszakot a szerző az „egypárti ellenőrzés a média felett” korszakként definiálja, főleg azon törvényi változások alapján, amelyek létrehozták a Nemzeti Médiaés Hírközlési Hatóságot. Valamint a legfrissebb 2019-es tanulmánya szerint olyan mértékben torzult 2010 óta a magyar média, hogy bizonyos vonásaiban már Putyin oroszországi médiájához hasonlítható (Bajomi-Lázár 2019). Jól mutatja a média kiemelt szerepét, hogy szinte azonnal a 2010-es választások után, már augusztusban megalapították az új szervezetet.

A kutatásokban gyakorta központi kérdés a média valós vagy vélt függetlensége (Polyák - Urbán 2016), a közmédia szerepe (Benson - Powers 2011, Bencsik 2018), vagy éppen az ideológiai megosztottság, polarizáció (Bernáth 2014). Jelen tanulmányban a magyar médiahálózat szerkezetét elemzem és azt feltételezem, hogy a 2015 óta tartó legújabb időszak második felében a médiahálózat szerkezete polarizált képet fest.

Ennek oka elsősorban a miniszterelnök és az üzletember Simicska Lajos konfliktusára vezethető vissza. Kettejük kapcsolata 2015 óta - a nyilvánosság számára is láthatóan - megromlott. Röviddel ezután a magyar médiavilág ismét mozgásba lendült, átrendeződött. Új médiumok jelentek meg, amelyeket már olyan vezetők irányítanak és olyan tulajdonosi háttérrel rendelkeznek, akik nyíltan kiállnak a kormány mellett. Ez alapján azt feltételezem, hogy a magyar médiavilág polarizált.

Három különböző politikai ügy kapcsán elemzem a magyar médiavilágot és háromféle módszerrel vizsgálom a médiumokat. Először leíró statisztikát készítek az egyes ügyekben megjelent kommunikációs aktivitások számáról. Utána a kiválasztott ügyekben megjelent aktivitásokat tartalmilag elemzem és kategorizálom. Végezetül a hálózatelemzés módszerét hívom segítségül. A hálózatelemzéshez az egyes kommunikációs aktivitásokban megjelenő hivatkozásokat rögzítem, majd így 


\section{KÖZELKÉP}

alkotom meg a hálózatot. Az interakciók fontosságát és integratív szerepét a korábban már a témában megjelent tanulmányok is megerősítik (Szabó - Bene 2015 a).

\section{Történeti áttekintés}

A 2010-es kormányváltás után érezhetően egy új rendszer jött létre Magyarországon. Kezdve a pártrendszer átalakulásával, amely földcsuszamlásszerű változáson ment keresztül egészen a médiáig (Körösényi 2015). Az új vezetés törekedett arra, hogy a nagyarányú győzelme ne csak egy alkalomra szóljon, ezért a választások után szinte azonnal átalakításokba kezdtek. Az új szabályozások közül is kiemelkedett a média területének szabályozása. A közmédiát kibővítették, és általuk megbízható embereket választottak a fontosabb pozíciókba. A média több területére is igyekeztek kiterjeszteni befolyásukat. Az egyik leghatékonyabb módszer erre nem az egyes médiumok cenzúrája, megfélemlítése vagy erőszakkal való elhallgattatása, hanem a gazdasági, pénzügyi befolyás megszerzése volt (Polyák et al. 2015, Bajomi-Lázár 2019).

A gazdasági befolyás megszerzésében több kormányhoz közeli vállalkozó is szerepet játszott, de közülük is kiemelkedik Simicska Lajos, Orbán Viktor egykori bizalmasa. A 2002-es választási vereség után az ő segítségével hozták létre a Hír TV-t, és müködtették tovább a Magyar Nemzetet, majd indítottak új rádiót, a Lánchíd Rádiót. A 2010-es kormányváltás után felgyorsultak az események. A Fidesz igyekezett befolyását kiterjeszteni minél több médiumra, így a portfólió 2016 végére már több mint 100 médiumot tartalmazott (Polyák 2017). Ezt a befolyást leginkább gazdasági eszközökkel tudta elérni, ezért a legfontosabb kérdéssé az vált, hogy kik a tulajdonosai egy-egy médiumnak és oda mennyi állami hirdetést sugároznak.

2015-ben fordulópont következett be kettejük kapcsolatában. Nehéz objektív, tényeken alapuló áttekintést adni a történtekről, hiszen a konfliktus nagyrészt a nyilvánosságtól elzárva, a színfalak mögött történt, azonban a következmények ismertek. Már 2014-től kezdve jelentek meg cikkek arról, hogy kettőjük kapcsolata megromlott, valamint néhány alkalommal vezető kormánypárti politikusok is a megszokottól eltérően nyilatkoztak a korábban kormánybarátként azonosított Hír TV-ről (Magyar Nemzet 2014). Végül 2015. február 6-án vált nyilvánvalóvá, hogy a viszony teljesen megromlott a miniszterelnök és régi bizalmasa között, amikor a Hír TV, a Magyar Nemzet és a Lánchíd Rádió vezetősége is benyújtotta a lemondását. Simicska Lajos pedig nyilatkozataiban tette egyértelművé, hogy ezen a napon egy korszak zárult le (Nagy 2015).

Az azt megelőző kormánypárti elköteleződést támasztotta alá Tarr Péter, Hír TV vezérigazgató-helyettes szavai is, amelyben megerősítette, hogy korábban a kormánypárti politikusok rendszeres eligazítást tartottak a csatornánál (Siposs 2015). A konfliktus után a Simicska Lajos érdekeltségébe tartozó médiumok látványosan 


\section{KÖZELKÉP}

más irányt vettek, a kormánypárti politikusok pedig innentől kezdve bojkottálták ezeket a médiumokat. Eközben egyes nagyhírű orgánumok, mint például a Népszabadság, hirtelen gyorsasággal megszűntek. Más médiumoknak akár napok leforgása alatt változott meg a tulajdonosi struktúrája.

2015 őszén több olyan médium is létrejött, amely Habony Árpád - miniszterelnöki tanácsadóhoz - köthető. Ilyen a 888.hu vagy a Lokál, és éppen ugyanebben az időszakban kezdte meg müködését a Magyar Idők is, valamint a megyei lapokat kiadó Mediaworksnek is megváltozott a tulajdonosi háttere. A konfliktus miatt a Simicska Lajoshoz köthető médiumok „ellenzéki” irányt vettek. A kormánypárt viszont igyekezett a korábbinál is nagyobb befolyást szerezni a média felett, gyorsan helyettesíteni a korábbi jobboldali médiumokat. Jóllehet, hogy Simicska Lajoshoz köthető médiumok „ellenzéki” szerepe 2015 után csak epizódszerep volt. A 2018-as választások után már nem tudta fenntartani sem a Lánchíd Rádiót, sem a Magyar Nemzetet. Végül először bezárták, majd a Hír TV és egyéb más médiumokkal együtt ezek is kormányközeli üzletemberekhez kerültek, így 2018 nyarának végére lezártnak tekinthető ennek a korszaknak az első szakasza.

A történeti áttekintés jól mutatja, hogy a magyar médiavilág kialakításában főszerepet játszott Simicska Lajos, de 2015-ben, a konfliktus hatására ez megváltozott. A konfliktus okán a kormánypárt további átalakításokba fogott, így az új médiumok és Simicska Lajos „visszavonulása” miatt, a korszak második szakaszáról beszélhetünk. A korszak 2018-as őszi szakaszát elemzem tanulmányomban, amikorra a Simicska-féle birodalom lényegében már megszűnt.

\section{Elméleti áttekintés}

A médiát gyakorta emlegetik negyedik hatalmi ágként. Bár a törvényhozó, végrehajtó és bírói hatalmi ágakkal szemben nem rendelkezik valódi hatalommal, a 20. század második felétől kezdve elmondható, hogy kiemelt szereppel bír. Ez Magyarországon sem alakult másképpen, a '90-es években az egyik legtöbb vitára okot adó ügy a média, a közmédia működése és felügyelete volt. A 2000-es években, amikor kvázi kétpártrendszer működött Magyarországon (Körösényi - Tóth - Török 2007) a médiakutatások fókuszában a médiumok pártossága, bal- és jobboldalisága határozta meg a kutatások egy jelentős részét.

A 2010-es kormányváltás óta nagyobb hangsúlyt kaptak a médiarendszer-elméletek is. Ennek oka, hogy a politikatudósok között jelentős vita alakult ki abban, hogy Magyarország milyen útra lépett 2010 után. A szakirodalom egy része illiberálisként, vagy antiliberálisként mutatja be az új politikai rendszert (Szelényi - Csillag 2015). Mások amellett érvelnek, hogy Magyarország többé már nem demokrácia (Ágh 2016, Kornai 2015). A politikai rendszer leírása mellett, a kutatások egy jelentős része a médiarendszerek felé mozdult el. A nemzetközi szakirodalom alapján, 


\section{KÖZELKÉP}

korábban számos tipizálás született az évtizedek folyamán, s legtöbbjük a mai napig viták tárgyát képezik. Sieber és munkatársai úttörő munkájukban négy nagy elméletet dolgoztak ki a médiarendszerekről. Az autoriter elmélet, libertariánus elmélet, szovjet-kommunista elmélet, társadalmi felelősség elmélet, amelyeknek lényege, hogy az egyes politikai rendszerekhez ideáltipikus médiaelméleteket társítanak (Sieber - Peterson - Schramm 1956). A korai elméletet más szerzők a 80-as, 90-es évek folyamán számos ponton finomították, elsősorban annak okán, hogy az eredeti tipizálásból kimaradtak a gazdasági aspektusok (Akhavan-Majid - Wolf 1991, Merrill - Lowenstein 1979). A médiarendszerek változása a politikai rendszerek változásához kötődik, állítják a kutatók, sőt Ostini és Fung a 2000-es évek elején már azt is felvetette, hogy azonos politikai rendszerben eltérő médiarendszerek múködnek (Ostini - Fung 2002). Amennyiben elfogadjuk ezeket a téziseket, az azt is jelenti, hogy Magyarországon 2010 után nem csak egy új politikai rendszer, hanem ezzel szinte egy időben egy új médiarendszer jött létre. Számos empirikus és elméleti tanulmány igyekezett megérteni az új médiarendszert, kezdve a gazdasági aspektusoktól, egészen a média centralizálásáig (Bajomi-Lázár 2019, Polyák et al. 2015, Polyák - Urbán 2016).

A média magas fokú centralizálásával gyakran felmerült az a vád - főként ellenzéki politikusok részéről - hogy a magyar média többé már nem szabad, s a kormány befolyása határozza meg jelentős mértékben a híreket. Nem csak a politikusok, hanem több tanulmány szerint is (Bajomi-Lázár 2019, Polyák 2017) a centralizáltság miatt a magyar média propagandisztikussá vált, bizonyos híreket elhallgatnak, másokat pedig másként tálalnak. Ha igazak ezek a feltételezések, akkor ez bebizonyítható a médiumok szisztematikus tartalomelemzésével, illetve statisztikai adatok gyüjtésével.

A médiavilág azonban nem csak az egyes médiumok által megjelentetett tartalmak vizsgálatával jellemezhető. Az egyes médiumok közötti kapcsolat, interakció éppen olyan fontos lehet, mint az általuk megjelentetett tartalom, hír. A 2010-es évek elején a magyarországi médiakutatások - köszönhetően a Jobbik előretörésének - egy igen jelentős része foglalkozott az egyes médiumok közötti kapcsolatokkal, azaz a magyar médiahálózattal (Szabó et al. 2015). Fontos kérdés, hiszen ha médiumok nem kapcsolódnak egymáshoz, akkor az akár alternatív médiahálózathoz, szubkulturális médiához vezethet. Sőt, a médiahálózat magas fokú polarizáltságát is mutathatja, amelyből további következtetéseket vonhatunk le a társadalomra, illetve egyes társadalmi folyamatokra.

Korábban a magyar médiahálózattal kapcsolatos tanulmányok azt a tézist erősítették, hogy a mainstream médiumok között nincs igazán különbség. A 2010-es évek elején fontos jelenség volt, hogy a radikális jobboldali médiumoknak nem sikerült betörniük a mainstream médiumok közé, habár erre kísérletet tettek. Illetve a kutatások azt is cáfolták, hogy Magyarországon a radikális jobboldali médiumok alternatív médiahálózatot hoztak volna létre (Szabó et al. 2015). A médiahálózatok kutatá- 


\section{KÖZELKÉP}

sa, tehát nem előzmény nélküli Magyarországon. Ezen tanulmányok (Szabó et al. 2015, Szabó - Bene 2015 b) főként olyan eseteken keresztül elemezték a médiavilág integritását, szerkezetét és polarizáltságát, amelyek az Orbán-Simicska konfliktus kirobbanása, tehát 2015 előtt történtek. Többségükben azt a tézist erősítették meg, amely szerint a magyar médiavilág egy olyan összetartó hálózat, ami rendelkezik integratív funkcióval is. A kormánypárti, baloldali, jobboldali médiumok egyaránt hivatkoznak egymásra, azaz tudomásuk van egymásról és nem tesznek különbséget egymás tudósításai között a vizsgált ügyek kapcsán (Szabó et al. 2015, Szabó - Bene 2015b). Ezeknél az eseteknél a média polarizáltsága, bal- és jobboldali vagy radikális jobboldali médiacsoportok kialakulása a hálózatban nem merült fel.

A fent említett kutatások csupán néhány évesek, mégis olyan mértékű változások történtek az Orbán-Simicska konfliktust követően, amelyek teljesen felforgatták a 2010 és 2015 között ismert médiavilágot. Ebből kifolyólag az új események kapcsán szükséges megvizsgálni a médiavilág szerkezetét és polarizáltságát, amelyre tanulmányomban kísérletet teszek.

A hálózatkutatás nemzetközi és magyar szakértői öt ideáltipikus hálózatot határoztak meg, amelyeket legjobban három mérőszám alapján lehet elkülöníteni. Ezek a hálózatok, nem csak a média világára alkalmazhatók, hanem bármely hálózatra, az emberi sejtektől kezdve, akár a repülési útvonalak hálózatáig. A szakirodalom alapján a három legfontosabb mérőszám a Fitness-érték, az átlagos legrövidebb távolság és a klaszteresedési mutató. Elemzésemben ezen mutatók alapján jellemzem a hálózatokat.

Az öt hálózattípus közül az első a centrum-periféria hálózat. A centrum-periféria hálózat jellemzője, hogy csomópontok sokasága alkotja a hálózat magját, amelyek szoros összeköttetésben állnak egymással. Hozzájuk lazán kapcsolódnak a magon kívüli egyéb csomópontok. A periférián lévő csomópontok ideális esetben nem kapcsolódnak egymáshoz, csak a magban lévő csomópontokhoz (Borgatti - Everett 1999). Ha elemzésem azt mutatja, hogy az egyes esetek centrum-periféria hálózatok, akkor az azt jelentené, hogy a magyar médiavilág egy mainstream csoportból és egy ehhez kapcsolódó egyéb médiumokból állna. Fontos kérdés, hogy mely médiumok kerülnek a hálózat magjába és melyek a perifériára, esetleg felfedezhető-e valamilyen mintázat.

A kisvilág hálózattípusnál a csomópontok kisebb, erősebb hálózatokat alkotnak, azonban ezek a kis klaszterek is kapcsolódnak egymáshoz. A kisebb klasztereken belül tehát jóval sűrűbb a csomópontok közötti összeköttetés, de az egyes klaszterek is lazán kapcsolódnak egymáshoz (Watts - Strogatz 1998). Ha az eredmények azt mutatják, hogy ilyen hálózat jött létre, akkor az azt jelentené, hogy különböző csoportok jöttek létre a magyar médiavilágban, amelyeken belül igen nagy az összetartás, de az egyes csoportok között is van interakció.

A klasztermentes kohezív hálózatban ezzel szemben nem jönnek létre külön csoportok, azaz klaszterek. A hálózat fő jellemzője, hogy a csomópontok nagyjából 


\section{KÖZELKÉP}

egyenlők és arányaiban ugyanúgy kapcsolódnak egymáshoz (Szabó et al. 2015). A médiavilág szempontjából ez azt jelentené, hogy nem jönnek létre csoportok, hanem egy nagy integrált hálózat létezik.

A polarizált hálózat hasonlít a kisvilág hálózatra, a különbség, hogy az egyes csoportok élesen elkülönülnek egymástól. A csoportokon belül sűrű kapcsolat van, azonban ellentétben a kisvilág hálózattal a csoportok között nincs kapcsolat (Angelusz - Tardos 2011, Conover et al. 2011.) Amennyiben ilyen típusú hálózat jött létre, akkor az azt jelentené, hogy teljesen elkülönült médiahálózatokról beszélhetünk, amelyek „buborékokként” működnek és nem vesznek tudomást egymásról.

Az ötödik típus pedig a diffúz hálózat. A diffúz hálózatnál nem jönnek létre csoportok. Jellemzője, hogy a csomópontok között nagy távolság van, és a hálózat széttöredezett (Szabó et al. 2015). Diffúz hálózat esetén a magyar médiavilág egy teljesen széttöredezett, nem integrált hálózat képét mutatná.

A részletes elemzés előtt érdemes röviden az alkalmazott mérőszámokkal foglalkozni. Az első a Fitness-érték, amely elsődlegesen azt mutatja meg, hogy egy hálózat mennyire hasonlít a centrum-periféria ideáltípushoz. A második, az átlagos legrövidebb távolság, amelyből megtudható, hogy az egyes csomópontok között átlagosan mekkora a távolság. A harmadik pedig a klaszteresedési mutató. A klaszteresedési mutató megmutatja, hogy az egyes hálózatokon belül előfordulnak-e klaszterek, csoportok.

A korábbi kutatások azt mutatják, hogy az olyan ügyeknél, amelyek országos hírűek - például a Paksi Atomerőmű bővítése, vagy a Jobbik számára egy kifejezetten kellemetlen hír, Kovács Béla kémügye 2014-ben - a médiahálózat egy összetartó, centrum-periféria képét mutatja. Ezekben a hálózatokban a vezető médiumok politikai oldaltól függetlenül a hálózat központjában állnak és a kisebb médiumok pedig a perifériáról igyekeznek ide bekapcsolódni (Szabó et al. 2015). A médiát napokig uraló botrányokról és ügyekről jó eséllyel feltételezhettük a 2010-2015-ös időszakban, hogy centrum-periféria hálózat képét mutatja.

\section{Kérdés, hipotézis és módszertan}

Az általam elvégzett előzetes vizsgálatok azt mutatják, hogy 2015 után egyes médiumok már teljesen ugyanazzal a kerettel tudósítanak bizonyos híreket (Varga 2018), sőt egyáltalán nem tudósítanak olyan hírekről, amely több millió embert érint. Ezért azt feltételezem, hogy ellentétben a korábbi kutatásokkal, a hálózat kevésbé egy centrum-periféria és sokkal inkább egy kisvilág hálózat vagy polarizált hálózat ismertető jegyeit mutatja.

A tanulmányban a hálózatokat interakciók révén alakítom ki. Az interakciókat egyes politikai ügyek kapcsán rögzítem, és az interakciók az egyes médiumok egymás közötti hivatkozásait jelentik. Egészen pontosan megvizsgálom, hogy egy 


\section{KÖZELKÉP}

adott hír, ügy kapcsán a médiumok milyen cikkeket, tudósításokat - összefoglalva milyen kommunikációs aktivitást - jelentettek meg, és ezekben a tartalmakban hivatkoznak-e egymásra. Ezzel a módszerrel olyan hálózat hozható létre, amely megmutatja, hogy 2018 őszén milyen képet mutat a magyar médiavilág. A hálózat jellegénél fogva mérhető lesz, így az elemzésemben megállapítható, hogy mely ideáltipikus hálózathoz áll közel a magyar média. Emellett a kommunikációs aktivitások rögzítésének köszönhetően egy leíró statisztikát is kapok, hogy a médiumok menynyit foglalkoztak az adott üggyel. Fontos kiemelni, hogy a kommunikációs aktivitások összesítése nem mutatja meg, hogy milyen minőségben, milyen hangvétellel tudósítottak az adott hírről a médiumok, ezért a vizsgálat során a tartalomelemzés módszerét is alkalmazom. Egyrészről a médiumok napirendjéről kapok információkat, amely arról árulkodik, hogy a média szerint miről kellene az embereknek gondolkodnia, másrészről az egyes tudósítások keretezéséről is, azaz hogy mit akar a média, hogyan gondolkodjanak az emberek egy adott ügyről (Török 2005, Weaver et al. 2004).

Ahhoz, hogy érthetővé váljon a polarizáció, legelőször azt szükséges meghatározni, hogy melyik médium áll közel a kormánypártokhoz. A korábban megjelent tanulmányok során (Szabó et al. 2015, Szabó - Bene 2015 a, Szabó - Bene 2015b) az MTA TK Politikai Kommunikáció Kutatócsoportjában szakértői becslés készült a 2014-ben működő médiumok politikai hovatartozásáról. A becslés során három politikai kommunikációval foglalkozó kutató sorolta be a médiumokat, jobboldali, baloldali/liberális, radikális jobboldali és semleges/nem besorolhatóként. A médiumok 63 százalékát mindhárman ugyanoda sorolták be, és további 26 százalékban ketten értettek egyet.

Az egyszerűsítés okán, jelen elemzésben nem kívánom „liberális”, „jobboldali”, „radikális” jelzőkkel illetni a médiumokat, hanem kétféle csoportot hozok létre. Az egyik csoport a kormánypárti médiumok, a másik pedig a nem kormánypárti médiumok. $^{3}$ Ehhez összefoglaló jelleggel áttekintem a korábban a szakértők által elkészített listát, illetve megvizsgálom az egyes újonnan létrejött médiumok tulajdonosi hátterét. Így nagy bizonyossággal állapítható meg, hogy egy-egy médium inkább a kormánypárthoz közeli, vagy éppen ellenkezőleg. A tulajdonosi háttér megfelelő jellemző annak eldöntéséhez, hogy a médium kormánypárti vagy sem, ezt erősíti meg

\footnotetext{
${ }^{3}$ A következő médiumokat kormánypártiként tartom számon: Magyar Televízió M1, Hír TV, TV2, Magyar Hírlap, Bors, Figyelő, Demokrata, Kossuth Rádió, origo.hu, borsonline.hu, mandiner.hu, magyarhirlap.hu, Echo TV, 888.hu, Magyar Idők, vs.hu, hirado.hu, magyaridok.hu, pestisracok.hu, lokal.hu, ripost.hu.

A következő médiumokat nem kormánypártiként tartom számon: ATV, RTL Klub, Népszava, Blikk, Magyar Narancs, 168 óra, index.hu, hvg.hu, 444.hu, blikk.hu, nepszava.hu, 24.hu, Info Rádió, azonnali.hu, atv.hu, alfahir.hu, magyarnarancs.hu, 168ora.hu, HVG.

Az elemzésbe nem került bele a Lokál, Magyar Narancs és a Ripost nyomtatott verziója, mert a lapszámok nem voltak elérhetőek, továbbá a Karc FM, Klub Rádió, mert nem rendelkezik archívummal. Az elemzésbe a vidéki, regionális médiumok sem kerültek bele.
} 


\section{KÖZELKÉP}

Bátorfy Attila a magyar médiáról szóló tanulmánya. Ebben arról írt, hogy a konfliktus előtt mindössze 14 olyan médium volt, amely szorosabb kapcsolatot ápolt a kormánypártokkal, a konfliktus után azonban 25 új médium jött létre, illetve 60 egyéb médiumot pedig felvásároltak a kormánypárthoz közelálló üzletemberek (Bátorfy 2017). Természetesen ebben benne vannak a vidéki médiumok is, amelyeket tanulmányomban nem vizsgálok, de a tendencia így is jól érzékelhető. Oly mértékben, hogy elemzések szerint a hír- és közéleti piacon, már 77,8\%-os túlsúlyban vannak a Fidesz-közeli médiumok (Mérték 2019).

Kutatásomban arra keresem a választ, hogy a magyar médiahálózat szerkezete polarizált képet mutat-e 2018 őszén, összekapcsolódnak-e a kormánypárti és nem kormánypári médiumok, illetve a megjelent tartalmi elemeket tekintve polarizált-e a magyar médiavilág.

Előzetesen azt várom, hogy a magyar médiahálózat szerkezete, a magyar médiavilág a korábbi kutatásokkal ellentétben (Szabó et al. 2015, Szabó - Bene 2015a, Szabó - Bene 2015b), 2018 őszén polarizált képet mutat. Továbbá a hálózat típusát tekintve kisvilág vagy polarizált ideáltipikus hálózatéhoz áll a legközelebb a magyar média szerkezete. A tartalomelemzés során szintén azt feltételezem, hogy a médiumok kommunikációs aktivitásaikat tekintve polarizáltak.

A könnyebb összehasonlíthatóság érdekében az ideáltipikus hálózatok jellemzőin nem változtatok. Az ideáltipikus hálózatokat és jellemzőit foglalja össze az 1. táblázat:

1. táblázat. Összefoglaló táblázat az ideáltipikus hálózatok jellemzőiről

\begin{tabular}{|l|c|c|c|}
\hline \multicolumn{1}{|c|}{ Hálózatok/Jellemzők } & Fitness érték & $\begin{array}{c}\text { Átlagos legrövidebb } \\
\text { távolság }\end{array}$ & $\begin{array}{c}\text { Klaszteresedési } \\
\text { mutató }\end{array}$ \\
\hline Centrum-periféra & $\sim 0,5$ & $2<$ & $\sim 0,5$ \\
\hline Klaszter mentes & $<0,5 ;$ & $1<\mathrm{x}<2$ & $<0,5$ \\
\hline Kisvilág & $<0,5 ;$ & $2<\mathrm{x}<3$ & $0,5<\mathrm{x}<1$ \\
\hline Polarizált & $<0,5 ;$ & $1<\infty$ & $0,5<\mathrm{x}<1$ \\
\hline Diffúz & $<0,5 ;$ & $3<\infty$ & $<0,5 ;$ \\
\hline
\end{tabular}

Forrás: Farkas 2016: 27

\section{Esetek kiválasztása}

Az elemzéshez három olyan esetet választottam ki, amelyek média- és hírértéke számottevő volt 2018 őszén és időben közel álltak egymáshoz, emellett országos érdeklődésre számot tartó ügyek. Továbbá, a kiválasztási szempontok között szerepelt, hogy az elemzésben olyan ügy jelenjen meg, amely negatívan érintette a kormányt, a 


\section{KÖZELKÉP}

kormánypártokat és olyan is, amely negatívan érintette az ellenzéket. Így az elemzés során láthatóvá válik, hogy egyes médiumok hogyan tudósítanak egy-egy ügyről. Harmadikként olyan ügyet választottam, amely nem kimondottan volt negatív vagy pozitív egyik fél számára sem.

Az első eset, amelyet elemzek, a miniszterelnök magánrepülőútját dolgozza fel (Erdélyi 2018). Ez az ügy, amely 2018 szeptemberében robbant ki, negatívan érintette a kormánypártokat, illetve a miniszterelnököt. Ezen az ügyön keresztül megvizsgálható, hogy a kormánypártokat negatívan érintő ügy esetén hogyan reagálnak az egyes médiumok.

A második a lakástakarék-törvény módosításáról szóló hírek (Előd 2018). Az ügy tulajdonképpen semleges a kormánypártok szemszögéből nézve. Egy gazdasági döntésnek is nevezhető, amely mellett lehetőségük volt érveket, másoknak pedig ellenérveket felsorakoztatni.

A harmadik Demeter Márta „repülős ügye” (hvg.hu 2018). Ez az ügy alapvetően a kormánypárt számára egy negatív hírrel robbant ki, azonban később erről bebizonyosodott, hogy téves információkon alapult. Így az ügy folyamán többféle álláspont is napvilágot látott, és néhány óra leforgása alatt az ügy az ellenzék számára kínos botránnyá alakult át. Ezt az ügyet azért érdemes részletesebb elemzés alá vetni, mert az ügy kezdeti szakaszában úgy tûnt, hogy ismét a kormánypártokat érinti negatívan. Azonban ahogy egyre több információ látott napvilágot, kiderült, hogy Demeter Márta tévedett. Így a kormánypártok és a kormánypárti médiumok arra használták fel ezt az ügyet, hogy rossz színben tüntessék fel az ellenzéket.

\section{Adatok, adatgyưjtés}

Orbán Viktor magánrepülővel kapcsolatos ügye 2018. szeptember 24-én robbant ki. Az ügy egészen október 8-áig húzódott, eközben a parlamentben is téma lett a „luxusrepülőzés”. A vizsgált időszak 2018. szeptember 24-től október 8-ig tart. Az online portálok anyagát alapul véve adatnak tekintettem minden cikket, amely találatként jött ki a „magánrepülő” szóra keresve az adott időszakban. Alternatív keresőszóként alkalmaztam a „magángép” kifejezést, ha a magánrepülő nem eredményezett találatot.

A második ügy a lakástakarék-törvény módosításával állt kapcsolatban, egy médiatudósításból kiindulva az eset 2018. október 15. és 29. között csúcsosodott ki: egy törvényjavaslat alapján az derült ki, hogy a kormány meg akarja szüntetni a takarékok után járó állami támogatást. A kormánynak különösen sürgős volt, hogy gyorsan elfogadják a törvényt, így ez az eset napok alatt zajlott le. Itt a „lakástakarék” keresőszót használtam. 


\section{KÖZELKÉP}

A harmadik ügyet Demeter Márta - ellenzéki képviselő - indította el, amikor írásbeli kérdést tett fel a honvédelmi miniszternek azzal kapcsolatosan, hogy miért honvédségi gépen szállították haza Ciprusról Orbán Viktor lányát. Mint később kiderült, Demeter Márta tévedett. Ennek oka az volt, hogy az egyik katona lányát ugyanúgy hívják, mint a miniszterelnökét. Ez az ügy szinte teljesen egybeesett a lakástakarék ügyével, 2018. október 15-től 29-ig tartott. Ennél az ügynél az adott intervallumon belül a „Demeter Márta” keresőszót használtam.

Bár az ügyek csúcspontjai csak néhány napig tartottak, az adatok gyűjtésénél a három ügy intervallumát kéthetes időszakra egységesítettem a könnyebb összehasonlíthatóság érdekében.

Az adatokat a következőképpen rögzítettem: minden ügynél az adott intervallumban a keresőszóra kiadott összes cikk manuális kódolása megtörtént. A televízió- és rádiócsatornáknál az adott nap esti, illetve főműsoridőben sugárzott híradó került bele a kódolásba, ezeknél nem volt szükséges a keresőszó használata. A nyomtatott sajtó anyagainál a vizsgálat időtartama alatt megjelent összes lapszámot kódoltam. Egy-egy konkrét kommunikációs aktivitásnál először rögzítettem, hogy az adott cikk, vagy tudósítás hivatkozott-e egy másik médiumra, valamint azt is, hogy milyen keretezéssel jelent meg. Besorolható-e az értelmezési keretek valamelyikébe? Egy kommunikációs aktivitáson belül többféle tartalmi elemet is rögzítettem, ha több szerepelt benne. Végül feljegyeztem azt is, hogy az adott ügyben egy-egy médiumnál hány darab kommunikációs aktivitás jelent meg. Az adatok rögzítésében segítségemre volt egy kódolótársam. Az adatok elemzéséhez Ucinet 6-et és a NetDraw (Borgatti et al. 2002) alkalmazásokat használtam.

Az előzetes kutatások azt mutatták, hogy mindegyik ügynél 3-4 értelmezési keret jelent meg. Ezenfelül létrehoztam egy „egyéb” kategóriát is, arra az esetre, ha egyikbe sem lehetne besorolni az adott tudósítás tartalmát. A tartalomelemzésnél a következő értelmezési kereteket állapítottam meg:

Orbán Viktor magánrepülőzésének értelmezési keretei:

1. Luxusrepülőzés, korrupció címke: A kommunikációs aktivitás úgy számol be az eseményről, hogy a miniszterelnök titokban, repülőt vagy luxusrepülőt használ, és/vagy felveti a repülőzés a korrupció gyanúját.

2. „Liberális média hazudik” címke: A kommunikációs aktivitásban elhangzik a felsoroltak közül bármely gondolat: szánalmas hazugságnak, baloldali médiakampánynak nevezi, korábbi baloldali politikusi ügyeket vagy Soros György nevét említi bármilyen okból.

3. „Fideszes politikus” címke: A kommunikációs aktivitásban fideszes politikus nyilatkozatát ismétli, idézi.

4. Egyéb: Minden olyan keretezés, amely a fentiekben nem jelent meg. 


\section{KÖZELKÉP}

Lakástakarékok ügye:

1. „Megszorítás” címke: A kommunikációs aktivitás úgy számol be az eseményről, hogy népszerű lehetőséget szüntet meg a kormány a lakástakarékok „kinyírásával”. Ha megemlíti, hogy gyorsan „keresztülveri” a parlamenten. Ha a következő gondolatok szerepelnek benne: rosszabb lesz az embereknek, nem konzultált a kormány senkivel.

2. „Kormány álláspontja” címke: Megjelenik benne a következő gondolatok egyike: költséges, de nem hatékony konstrukció, extraprofit, nem szolgálja az eredeti célokat.

3. „Fideszes politikus” címke: Fideszes politikus nyilatkozatát idézik, vagy ismétlik.

4. Egyéb: Minden olyan keretezés, amely a fentiekben nem jelent meg.

Demeter Márta ügye:

1. „Beszámol az eseményről” címke: A kommunikációs aktivitás úgy számol be az eseményről, hogy Demeter Márta szerint Orbán lánya utazott a géppel, és erről kérdéseket tett fel, többé-kevésbé tárgyilagos mondatokban. Például nem azt mondja, hogy hazudik, hanem hogy tévedett, tévedésből. Fontos, hogy ismerteti az ügy mindkét részét, tehát az eredeti kérdésfeltevést is és a tévedést is.

2. „Fake News” címke: Minden olyan kommunikációs aktivitás, amely úgy számol be az esetről, hogy Demeter Márta hazudik, nem mond igazat. Soros György említése, „fake news” kifejezés említése.

3. „Fideszes politikus” címke: A kommunikációs aktivitás fideszes politikus nyilatkozatát idézi, ismétli.

4. Egyéb: Minden olyan keretezés, amely a fentiekben nem jelent meg.

\section{Eredmények}

Összesen 41 különböző médium szerepel az adatbázisban, amelyek közül 21 médiumot soroltam a kormánypárti médiumok közé és 20 médiumot nem kormánypárti médiumként kategorizáltam. A három ügyben rendkívül nagyszámú kommunikációs aktivitás született. Magánrepülő esetében 194, lakástakaréknál 324, és Demeter Márta ügyében 308-at kódoltam az adott időszak alatt.

A 2. táblázat megmutatja a kormánypárti és a nem kormánypárti médiumok megoszlását a megjelent kommunikációs aktivitások száma szerint: 


\section{KÖZELKÉP}

2. táblázat. A megjelent kommunikációs aktivitások darabszáma ügyenként

\begin{tabular}{|l|c|c|c|}
\hline & Magánrepülő & Lakástakarék & Demeter Márta \\
\hline Összes megjelent tudósítás & 194 & 324 & 308 \\
\hline $\begin{array}{l}\text { Kormánypári médiumban jelent } \\
\text { meg }\end{array}$ & 23 & 85 & 196 \\
\hline $\begin{array}{l}\text { Nem kormánypárti médiumban } \\
\text { jelent meg }\end{array}$ & 171 & 239 & 112 \\
\hline
\end{tabular}

Forrás: Saját szerkesztés

A 2. táblázat adatai alapján szembetűnő, hogy a kormánypárti médiumok szinte alig számoltak be a miniszterelnök számára kellemetlen magánrepülő ügyről. A médiában ezzel kapcsolatosan megjelent kommunikációs aktivitásnak mindössze 11,8\%-át jelentették meg ők. A lakástakarék ügyénél már 26,2\%-ot, de ez sem volt túl hangsúlyos. Azonban Demeter Márta ügyénél kiugróan nagy számot kapunk, a tudósítások 63,6\%-a már a kormánypárti médiumokhoz köthető.

A kormánypárti médiumok jól érzékelhetően kevésbé számolnak be azokról az ügyekről, amelyek kellemetlenek a kormány számára, ami azt is jelenti egyben, hogy a kormánypárti és nem kormánypárti médiumok napirendje jelentős különbséget mutat. Főként igaz ez a miniszterelnök magánrepülős ügyénél. Még érdekesebb, ha a tartalomelemzés eredményeit is figyelembe veszem. Ha mind a 23 kormánypárti médiumban megjelent kommunikációs aktivitást megvizsgálom a miniszterelnök ügyében, akkor mindösszesen négyszer fordult elő, hogy a luxusrepülőzés, korrupció címkéjét fel lehetett fedezni (3. táblázat). A maradék 28 kódolt esetben 15-ször azt közvetítették, hogy nem mond igazat a liberális média. Nyolcszor fideszes politikus nyilatkozatát idézték, és csupán 5 esetben nem sikerült kategorizálni az aktivitást.

Elmondható, a kormánypárti médiumok a miniszterelnök számára kellemetlen ügyről szinte alig számoltak be, és ha be is számoltak, akkor azt úgy tették, hogy vagy fideszes politikus nyilatkozatát idézték, vagy arról tudósítottak, hogy az úgynevezett „fake news” médiumok - tehát a nem kormánypártiak - hazudnak. A nem kormánypárti médiumok ezzel szemben főként úgy számoltak be az esetről, hogy az felveti a korrupció gyanúját, és a miniszterelnök magyarázattal tartozik, hogyan is engedhet meg magának egy magánrepülő utat. Ez a gondolat 125-ször fordult elő a kommunikációs aktivitásokban. Az nem merült fel egyik nem kormánypárti médiumnál sem, hogy hazudna a média, viszont 55 alkalommal ők is fideszes politikus nyilatkozatát közvetítették. 15 alkalommal egyik fentebbi címkét sem tudtam azonosítani, így ezek az egyéb kategóriába kerültek. Utóbbiakban néhányszor ellenzéki politikusok nyilatkozatai is felfedezhetők, azonban számuk alacsony. 


\section{KÖZELKÉP}

3. táblázat. A magánrepülő ügyében megjelent kommunikációs aktivitások tartalmuk szerint

\begin{tabular}{|l|c|c|c|c|}
\hline & $\begin{array}{c}\text { Luxusrepülő, } \\
\text { korrupció }\end{array}$ & $\begin{array}{c}\text { „Fake news”, } \\
\text { hazudik } \\
\text { a liberális média }\end{array}$ & $\begin{array}{c}\text { Fideszes } \\
\text { politikus } \\
\text { nyilatkozta }\end{array}$ & Egyéb \\
\hline $\begin{array}{l}\text { Kormánypárti médiumban } \\
\text { jelent meg }\end{array}$ & 4 & 15 & 8 & 5 \\
\hline $\begin{array}{l}\text { Nem kormánypárti médi- } \\
\text { umban jelent meg }\end{array}$ & 125 & 0 & 55 & 15 \\
\hline
\end{tabular}

Forrás: Saját szerkesztés

Összességében a miniszterelnök számára kellemetlen ügyben a kormánypárti médiumok, vagy nem hozzák le a híreikben, vagy ha tudósítanak is róla, akkor azt olyan hangsúllyal teszik, hogy semmiképpen ne legyen kellemetlen a kormánypárt számára. Egy országos érdeklődésre számot tartó ügy, amely kifejezetten a miniszterelnök személyét érinti, a 23 megjelent kommunikációs aktivitás 21 kormánypárti médiumra vetítve kéthetes időszak alatt nem mondható kiugró értéknek. Ez azt jelenti, hogy a kormánypárti médiumoknak egyenként átlagosan 1,1 kommunikációs aktivitásuk volt az ügyről, és ezen aktivitás során - ahogyan azt a tartalomelemzés megmutatta - inkább azt fejtegették, hogy nem igazak azok az állítások, amelyek megjelentek más médiumokban, vagy fideszes politikus nyilatkozatát idézik. Továbbá az adatok azt támasztják alá, hogy az ügy gyakorlatilag láthatatlan volt a kormánypári médiumot fogyasztók körében. Ezzel szemben a nem kormánypárti médiumok átlagosan 8,5 kommunikációs aktivitást jelentettek meg a vizsgált időszak alatt. Ez a szám nem egyenletesen oszlik meg a két hét alatt, viszont jól érzékelteti, mekkora a különbség a kormánypárti és nem kormánypárti médiumok között. A nem kormánypárti médiumok döntő többségében úgy számoltak be az esetről, hogy az felveti a korrupció gyanúját, de sok esetben fideszes politikusok nyilatkozatát is idézték. Gyakran jelent meg mindkét tartalmi elem egyszerre egy tudósításon belül is. Ennél az ügynél tehát a médiumok napirendje és a megjelenített keret is jelentős eltéréseket mutatott a két csoport között.

Elemzésem második fókusza, a lakástakarékok ügyének vizsgálata sokban hasonlít a már tárgyalt magánrepülő ügyhöz. Ennek az ügynek az az érdekessége, hogy a kormánypártok tudták, hogy egy kényesebb gazdasági intézkedést kívánnak villámsebességgel meghozni, így akár kommunikációs paneleket is gyárthatnak mellé. Az adatfelvételnél kiderült, hogy valószínűleg ez így zajlott. Bár a törvényt a lehető leggyorsabban szerették volna elfogadtatni a parlamenttel - ez is azt mutatja, hogy sejtették, hogy ez nem lesz népszerű intézkedés -, de így sem kerülhették el az óriási médiaérdeklődést. Érthető, hiszen ez az intézkedés több százezer embert érintett közvetve vagy akár közvetlenül is. Ezzel szemben a kormánypárti médiumokban ismételten kevesebb figyelmet kapott az ügy, a vizsgált időszak alatt összesen 85 


\section{KÖZELKÉP}

kommunikációs aktivitás jelent meg (4. táblázat), ami 21 médiumra vetítve megközelítőleg egyenként négyet jelentett. Ez magasabb mutató a korábbi 1,1-es egy médiumra eső átlagos kommunikációs aktivitás számával a magánrepülős ügyhöz képest. A nem kormánypárti médiumok sokkal nagyobb arányban számoltak be az eseményekről, 239 kommunikációs aktivitásuk volt, ami átlagosan majdnem 12 aktivitást jelent médiumonként az adott időszakra. Ez azt jelenti, hogy az események folyamán átlagosan akár naponta 2-3 aktivitás is megjelent ezzel az üggyel kapcsolatban mindegyik nem kormánypárti médiumnál.

4. táblázat. A lakástakarékok ügyében megjelent kommunikációs aktivitások megoszlása tartalmuk szerint

\begin{tabular}{|l|c|c|c|c|}
\hline & Megszorítás & $\begin{array}{c}\text { Kormány } \\
\text { álláspontja }\end{array}$ & $\begin{array}{c}\text { Fideszes politikus } \\
\text { nyilatkozata }\end{array}$ & Egyéb \\
\hline $\begin{array}{l}\text { Kormánypárti } \\
\text { médiumban jelent meg }\end{array}$ & 4 & 47 & 47 & 16 \\
\hline $\begin{array}{l}\text { Nem kormánypárti } \\
\text { médiumban jelent meg }\end{array}$ & 149 & 7 & 53 & 64 \\
\hline
\end{tabular}

Forrás: Saját szerkesztés

Ha megvizsgáljuk a megjelent kommunikációs aktivitásokat tartalmuk szerint, akkor ismételten hasonló arányokat tapasztalunk, mint a magánrepülős ügynél. A kormánypárti médiumok szinte kivétel nélkül úgy számoltak be az eseményekről, ahogyan a kormány, emellett a fideszes politikusok nyilatkozatát idézték. Mindöszszesen négy esetben történt olyan, hogy egy kormánypárti médium tudósításában szerepelt az a gondolat, hogy az új törvény esetleg kényelmetlenül érintheti az embereket. Ezzel szemben, a nem kormánypárti médiumok kommunikációs aktivitásaiban túlnyomó többségében ez a keretezés jelent meg. Mindössze hét kommunikációs aktivitásban vették át a kormány narratíváját, amely főként a luxusprofitra és arra vonatkozott, hogy a konstrukció nem szolgálja az emberek érdekeit. 53-szor jelent meg fideszes politikusok nyilatkozata, és 64 alkalommal egyéb, egyik kategóriába sem sorolható tartalmat közvetítettek. A többi ügyhöz képest ez utóbbi kiugró érték (64), ezekben az esetekben főként az általános ingatlanpiaci helyzetet elemezték, illetve sok esetben statisztikákat közöltek a már meglévő lakástakarékokról.

Megállapítható, hogy a médiumok között a kommunikációs aktivitások hangsúlyát tekintve ismét jelentős különbség észlelhető. A kormánypárti médiumok csak a kormány narratíváját mutatják be, illetve fideszes politikusok nyilatkozatait, amelyek szintén a kormány narratíváját idézik. Ezzel szemben a nem kormánypárti médiumok nagy hangsúlyt fektettek arra, hogy az ügy egyéb aspektusairól tudomást szerezzenek az emberek, emellett gyakran idézték a fideszes politikusok gondolatait is. A kormánypárti és nem kormánypárti médiumok között ebben az esetben ki- 


\section{KÖZELKÉP}

sebb volt a megjelent aktivitások számbeli eltérése, tehát a két csoport napirendje közelített egymáshoz, de a tartalmi polarizáció továbbra is tetten érhető. A kormánypárti médiát fogyasztók - akárcsak a magánrepülő ügyénél - meglehetősen egyoldalú információt kaptak.

Tanulmányom középpontjában álló harmadik eset, Demeter Márta ügye a kirobbanásakor úgy indult, mintha megismétlődne a korábbi magánrepülős ügy. Azonban hamar kiderült, hogy tévedett, és így könnyed támadási felületet jelentett a kormánypártok és a kormánypárti médiumok számára is.

Az ügyben a vizsgált időszak alatt 308 kommunikációs aktivitás jelent meg (lásd 5. táblázat), amelyből 196 a kormánypárti médiumokban és 112 a nem kormánypárti médiumokban került közreadásra. Látható, hogy a kormánypárti médiumok jelentősen aktivizálták magukat az ügyben. A megjelent kommunikációs aktivitások körülbelül kétharmada köthető hozzájuk, ezzel szemben a nem kormánypárti médiumokhoz csupán az egyharmada. Ez azt jelenti, hogy a vizsgált időszakban a kormánypárti médiumok átlagosan 9,3 kommunikációs aktivitást jelentettek meg, a nem kormánypárti médiumok viszont csak 5,6-ot, amely elmarad a korábbi 12-es és 8,5-es átlagos darabszámtól.

5. táblázat. A Demeter Márta ügyében megjelent kommunikációs aktivitások tartalma

\begin{tabular}{|l|c|c|c|c|}
\hline & $\begin{array}{c}\text { Beszámol } \\
\text { az eseményekről }\end{array}$ & „Fake news” & $\begin{array}{c}\text { Fideszes politikus } \\
\text { nyilatkozata }\end{array}$ & Egyéb \\
\hline $\begin{array}{l}\text { Kormánypárti } \\
\text { médiumban jelent meg }\end{array}$ & 12 & 102 & 113 & 10 \\
\hline $\begin{array}{l}\text { Nem kormánypárti } \\
\text { médiumban jelent meg }\end{array}$ & 53 & 9 & 55 & 16 \\
\hline
\end{tabular}

Forrás: Saját szerkesztés

Demeter Márta ügyénél három fő kategóriát különítettem el. Az első kategóriába tartozó tartalmi elemek azok voltak, amikor egy médium többé-kevésbé tárgyilagosan számol be az eseményekről, bemutatja annak mindkét oldalát. Ennél a kategóriánál a nem kormánypárti médiumok jártak élen, 53 esetben jelentek meg így kommunikációs aktivitások, ameddig a kormánypárti médiumoknál mindösszesen 12 volt ez a szám. Ennél az ügynél szinte azonnal megjelent az úgynevezett „fake news” keretezés. A kormánypárti médiumok azonnal hazugnak nevezeték a nem kormánypárti médiumokat, amiért tudósítottak Demeter Márta tévedéséről. Gyakorlatilag a kormánypárti médiumoknál vagy az jelent meg az ügyről, hogy a „liberális média hazudik", vagy egy fideszes politikus nyilatkozatát jelentették meg. Ezzel szemben a nem kormánypárti médiumok igyekeztek beszámolni a teljes eseménysorozatról, és arról is, hogy Demeter Márta tévedett. Emellett a többi ügyhöz hasonlóan fideszes politikusok nyilatkozatát is idézték. A fő különbség a két csoport között, hogy a nem 


\section{KÖZELKÉP}

kormánypárti médiumok nagyobb számban számoltak be az ügy előzményeiről is, míg a kormánypárti médiumok már csak arról tudósítottak, hogy az eset nem úgy történt, ahogy az először megjelent a másik csoport médiumainál. A média napirendjében ennél az ügynél volt a legkisebb különbség a csoportok között, és ez szintén igaz a polarizációra is.

A tartalomelemzés egyértelművé tette, hogy a kormánypárti médiumok nem kiegyensúlyozottan számolnak be egy-egy ügyről, ameddig a nem kormánypárti médiumoknál nem volt ilyen jelentős a különbség. Mind mennyiségében, mind a tudósítások keretezésében jelentős különbségek vannak a kormánypárti és nem kormánypárti csoport között. Az egyetlen kapcsolatot a médiumok között jelenlévő szakadék felett az jelenti, hogy a nem kormánypárti médiumok is jó eséllyel megjelentetik tudósításaikban a fideszes politikusok nyilatkozatait. Ez az egyetlen motívum, amely mind a két fél kommunikációs aktivitásaiban jelen van, ezenkívül legyen szó bármelyik ügyről, a kormánypárti és nem kormánypárti médiumok teljesen más hangsúllyal számolnak be az ügyekről, ami magas fokú polarizáltságra utal.

\section{Hálózatelemzés}

A hálózatelemzést az elméleti és módszertani részben kifejtett mérőszámok alapján készítettem el.

A magánrepülő ügyében a hálózat Fitness-értéke 0,539, amely megmutatja, hogy a korábbi elemzésekhez hasonlóan a hálózat egy úgynevezett centrum-periféria hálózathoz hasonlítható leginkább. Magjába a legaktívabb médiumok kerültek, jelen esetben csak azok, amelyek nem kormánypárti médiumokként kerültek definiálásra. Az átlagos legrövidebb távolság 1,868, ami tovább valószínúsíti a centrum-periféria hálózat jelleget. A klaszteresedési együttható viszont 0,712-es értéket mutat, ami igen magas, így ez a hálózat leginkább egy centrum-periféria hálózat jellegét veszi fel, amelyben magas a klaszteresedés. Azonban ez megtévesztő is lehetne, hiszen nem beszélhetünk kormánypárti és nem kormánypárti médiabuborékról, mert a kormánypárti médiumok igen jelentős hányada be sem került a hálózatba, mivel egyáltalán nem voltak aktívak. Így a klaszteresedés valószínűsíthetően a magban jött létre, amelyet a nem kormánypárti médiumok alkotnak, s ehhez kapcsolódik a többi kormánypárti médium egy-egy vékony szálon. Ennél az ügynél a következő médiumok kerültek a hálózat centrumába: index.hu, 24.hu, 444.hu, hvg.hu, atlatszo.hu, 168ora.hu. Ezek között a médiumok között volt a legszorosabb kapcsolat, a többi médium leginkább a hálózat perifériájáról igyekezett bekapcsolódni.

A lakástakarékok ügyénél a Fitness-érték már egy jóval magasabb 0,686-os értéket mutat. Ennek oka, hogy a nem kormánypárti médiumok is részt vettek az ügy tudósításában. Az átlagos legrövidebb távolság hasonlóan az első esethez 1,931-es érték lett, azonban a kalszteresedési mutató már sokkal alacsonyabb, csak 0,198. 


\section{KÖZELKÉP}

Ilyen alacsony klaszteresedési mutatónál felmerül, hogy diffúz hálózattal van-e dolgunk, ahhoz azonban jóval magasabb átlagos legrövidebb távolság szükséges. Így a lakástakarékok ügyéből alkotott hálózat leginkább egy centrum-periféria hálózatnak mondható, amelyben egyáltalán nem mutathatók ki a klaszteresedés jellemzői. A hálózat centrumában továbbra is a nem kormánypárti médiumok állnak: 168ora.hu, 24.hu, portfolio.hu, hvg.hu, blikk.hu.

Demeter Márta ügyénél adódott a legmagasabb, 0,869-es Fitness-érték. Ennél az ügynél léptek be a leghatározottabban a hálózatba a nem kormánypárti médiumok. Az átlagos legrövidebb távolság 2,150-es értékủ lett, amely némileg magasabb az előzőeknél, de ennek elsődleges magyarázata, hogy a legtöbb nem kormánypárti médium erről az ügyről igen intenzíven tudósított, amelynek következtében a hálózat nagyobb lett. A klaszteresedési mutató szintén alacsony, 0,433-as értéket mutat, így ismételten nem beszélhetünk elkülönült buborékokról. Hovatovább, a három vizsgált hálózat közül - köszönhetően a kormánypárti médiumoknak - ez a hálózat cáfolja leginkább a polarizáció elméletét. Ezzel együtt legjobban hasonlít a centrum-periféria ideáltipikus hálózatára. Centrumában vegyesen szerepelnek kormánypárti és nem kormánypárti médiumok is, és fóként a kisebb médiumok szorultak a perifériára.

Érdemes megvizsgálni, hogy az egyes csoportok között és a csoportokon belül milyen volt az áthivatkozások aránya, hogy részletesebb képet kapjunk a csoportok közötti kötődésekről. A magánrepülő ügyénél összesen 190 hivatkozást sikerült rögzíteni, ebből 82-t kapott az atlatszo.hu. Ez azzal magyarázható, hogy az atlatszo.hu indította el a botrányt. A 82-ből mindössze 7 érkezett nem kormánypárti médiumtól. Az összes kormánypárti médium 15-ször hivatkozott más médiumra, ebből 8-szor az origo.hu-t idézték és 7-szer az atlatszo.hu-ra mutattak a hivatkozások. Ezzel szemben a kormánypárti médiumok 27 hivatkozást kaptak a nem kormánypárti médiumoktól. Ennél az ügynél a kormánypárti médiumok szinte teljesen láthatatlanok maradtak.

A lakástakarékok ügyénél 115 hivatkozást rögzítettem. Ebben az esetben a hvg.hu kapta a legtöbb hivatkozást, szám szerint 16-ot. A 16 közül mindösszesen egy érkezett kormánypárti médiumtól. A 115 hivatkozásból szerény számban, csak 12szer hivatkoztak a kormánypárti médiumok valamely más médiumra. Ezzel szemben a nem kormánypárti médiumok 103-szor tették ugyanezt. A 12-ből háromszor a saját csoportjukon belül hivatkoztak és 9-szer nem kormánypárti médiumokra.

A Demeter Márta ügyében készült hálózat mondható a legsürűbbnek az interakciókat tekintve. Ennél az ügynél 239 hivatkozást rögzítettem. A kormánypárti médiumok is jóval nagyobb aktivitást mutattak az ügyben. A legtöbb hivatkozást most nem az a médium kapta, amelyik kirobbantotta az ügyet, hanem az origo.hu, szám szerint 36-ot. Ezt követte az ügy kirobbantója, az azonnali.hu, amely 28 hivatkozást kapott, a hvg.hu szintén 28-at majd az index.hu 22-t. Ebben az esetben a kormánypárti mé- 


\section{KÖZELKÉP}

diumok 176-szor hivatkoztak egymásra. Ebből 103-szor nem kormánypárti médiumokat és 73-szor pedig kormánypárti médiumokat. Ennél az ügynél a nem kormánypárti médiumok mutattak kevesebb aktivitást, hiszen mindössze 63-szor hivatkoztak másra. Ebből 23-szor kormánypárti médiumokra és a többi esetben saját csoportjukon belül történt a hivatkozás.

A hálózatok elemzésénél vegyes eredményeket kaptam. Az első két esetben a kormánypárti médiumok szinte alig vesznek részt a médiahálózatban, ezért a polarizáció tézisét el kell, hogy vessem. A polarizált médiahálózathoz legalább két feltételnek kellett volna teljesülnie a kormánypárti médiumok részéről. Az első, hogy részt vesznek a médiahálózatban, azaz hivatkoznak vagy hivatkozásokat kapnak. A második pedig, hogy ezek a hivatkozások csoporton belül történnek. Ennél a két esetnél egyik feltétel sem teljesült. Demeter Márta ügyének médiareprezentációja egy árnyalatnyival más képet mutat. Itt a kormánypárti médiumok igen nagy aktivitást mutattak, szemben a nem kormánypárti médiumokkal, melyeknek csökkent az első két vizsgált ügyhöz képest az aktivitása. Viszont az adatok továbbra sem erősítik meg a polarizáció tézisét, mert a csoportok közötti interakciók száma túl magas volt ahhoz, hogy elkülönült csoportokról beszéljünk. A két csoport nem zárkózott el attól, hogy egymást hivatkozza, így polarizáció ebben a hálózatban sem merült fel.

\section{Összegzés}

Tanulmányomban három ügy kapcsán vizsgáltam a magyar médiában fellelhető polarizáció tézisét. A történeti és elméleti áttekintés során amellett érveltem, hogy a kormánypárti és nem kormánypárti médiumok között igen magas a polarizáció 2018 őszén. Hogy ezt bebizonyítsam, három módszerrel közelítettem meg a kérdést. Három ügy kapcsán adatokat gyűjtöttem a megjelent hírek számáról, ezek keretezéséről és arról, hogy az egyes médiumok mennyire lépnek interakcióba egymással.

A leíró statisztika megmutatta, hogy a kormánypárti és nem kormánypárti médiumok napirendje jelentősen eltér egymástól. Ha a kormánypártok számára egy kellemetlen, negatív ügy jelenik meg a médiában, akkor alig aktivizálják magukat, szinte nem jelentetnek meg róla egyetlen hírt sem. Ezzel szemben, ha egy olyan ügyről van szó, ami az ellenzék számára lehet kellemetlen, akkor nagyfokú aktivitást mutatnak, ilyenkor pedig a nem kormánypárti médiumok aktivitása csökken.

A tartalomelemzés módszere szólt leginkább a polarizáció tézise mellett. Megvizsgáltam, hogy az egyes kommunikációs aktivitások milyen tartalmi elemekkel jelentek meg és ez alapján kijelenthető, hogy a két csoport tartalmi elemei teljesen különböztek egymástól mindegyik ügynél. Ez alól kivételt jelent, hogy a nem kormánypárti médiumok is megjelentetik fideszes politikusok nyilatkozatát, ezáltal fellelhető némi kapocs a tartalmi buborékok között. 


\section{KÖZELKÉP}

A hálózatelemzés és az ismertetett ideáltipikus hálózatok alapján azonban nem nyert bizonyítást az a tézis, miszerint a magyar médiahálózat egy polarizált hálózat képét mutatná. Továbbra is a centrum-periféria felosztás a legvalószínűbb. Ennek egyik oka, hogy az első két esetnél a kormánypárti médiumok nem is igazán kapcsolódtak be a hálózatba, a harmadik esetnél, ahol pedig bekapcsolódtak, ott mindkét csoport interakcióba lépett egymással, ennek következtében a polarizáció kizárható.

Összességében megállapítható, hogy a két csoport napirendje jelentős eltéréseket mutatott 2018 őszén. Ezen felül, ha azonos napirendre kerültek, akkor pedig a tartalmi elemekben további eltérés, jelentős polarizáció mutatkozott.

\section{Irodalom}

Ágh A. (2016): The Decline of Democracy in East-Central Europe. Hungary as the Worst-Case Scenario. Problems of Post-Communism 63(5-6): 277-287. https://doi.org/10.1080/10758216.2015.1113383

Akhavan-Majid, R. - Wolf, G. (1991): American mass media and the myth of libertarianism: Toward an "elite power group" theory. Critical Studies in Mass Communication 8. évf., 2., 139-151. https://doi.org/10.1080/ 15295039109366787

Angelusz R. - Tardos R. (2011): Régi és új törésvonalak, polarizáció, divergenciaspirál. In: Tardos R. - Enyedi Zs. - Szabó A. (szerk.): Részvétel, képviselet, politikai változás. DKMKA, Budapest, 347-382.

Bajomi-Lázár P. (2019): A patrónusi-kliensi médiarendszer és az újságírói szükségletek Maslow-piramisa. Médiakutató 20(1): 41-58.

Barabási A. L. (2006): A hálózatok tudománya a társadalomtól a webig. Magyar Tudomány 167(11): 1298-1308.

Bátorfy A. (2017): Az állam foglyul ejtésétől a piac fogvatartásáig. Médiakutató 18(1-2): 7-30.

Bencsik M. (2018): Szúrópróba 27. Mérték Médiaelemző Múhely 2018. szeptember.

Benson, R. - Powers, M. (2011): Public Media and Political Independence. Free Press, Washington DC.

Bernáth G. (2014): Harc a jelenlétért és a jelentésért. Magyarországi szélsőségesek és a média fôsodrának rutinjai. Médiakutató 15(3): 101-114.

Borgatti, S. - Everett, M. G. (1999): Models of core periphery structure. In: Social Networks 21(4): 375-396. https://doi.org/10.1016/s0378-8733(99)00019-2

Borgatti, S. - Everett, M. G. - Freeman, L. C. (2002): Ucinet for Windows: Software for Social Network Analysis. Analytic Technologies. Harvard, MA. 


\section{KÖZELKÉP}

Conover, M. D. - Ratkiewicz, J. - Francisco, M. - Goncalves, B. - Flammini, A. - Menczer, F. (2011): Political polarization on Twitter. Fifth International AAAI Conference on Weblogs and Social Media.

Enyedi Zs. - Kenneth, B. (2011): Kritikus választás 2010. A magyar pártrendszer átrendeződése a bal-jobb dimenzióban. Enyedi Zs. - Szabó A. - Tardos R. (szerk.): Új képlet. Választások Magyarországon. DKMKA, Budapest.

Farkas A. (2016): Radikális jobboldali médiumok és a politikusok a magyar médiahálózatban. Szakdolgozat, Budapesti Corvinus Egyetem.

Kornai J. (2015): Hungary's U-turn. Capitalism and Society 10(2): 2-24. https://doi.org/10.1353/jod.2015.0046

Körösényi A. (2015): A magyar demokrácia három szakasza és az Orbán-rezsim In: Körösényi A. (szerk.): A magyar politikai rendszer - negyedszázad után. Osiris, Budapest.

Körösényi A. - Tóth Cs. - Török G. (2007): A magyar politikai rendszer. Osiris, Budapest.

Merrill, J. C. - Lowenstein, R. L. (1979): Media, Messages and Men: New Perspectives in Communication. Longman, New York.

Ostini, J. - Fung, H. (2002): Beyond the Four Theories of the Press: A New Model of National Media Systems. Mass Communication \& Society 5(1): 41-56. https://doi.org/10.1207/s15327825mcs0501_4

Polyák G. - Mong A. - Nagy K. - Urbán Á. - Uszkiewicz, E. (2015): Elfogy a levegő: Lágy cenzúra a médiában. Mérték Médiaelemző Műhely.

Polyák G. - Urbán Á. (2016): Az elhalkítás eszközei. Politikai beavatkozások a médiapiac és a nyilvánosság működésébe. Médiakutató 16(3-4): 109-123.

Siebert, F. - Peterson, T. - Schramm, W. (1956): Four theories of the press: The authoritarian, libertarian,social responsibility, and Soviet communist concepts of what the press should be and do. Urbana: University of Illinois. Champaign.

Szabó G. - Bene M. (2015a): Hivatkozlak, tehát vagy(ok)!: Kommunikáció kapcsolatok a magyar médianyilvánosságban In: Szabó G. (szerk.): Politika az intézményeken túl: Kapcsolatok, interakciók, élmények. MTA TK PTI, Budapest.

Szabó G. - Bene M. (2015b): Mainstream or an alternate universe? Locating and analysing the radical right media products in the Hungarian media network. Intersections: East European Journal Of Society And Politics 1(1): 122-146. https://doi.org/10.17356/ieejsp.v1i1.30

Szabó G. - Bene M. - Antal A. - Farkas A. (2015): Kívül tágasabb! Radikális jobboldali médiumok a magyar médianyilvánosság hálózataiban. Politikatudományi Szemle 24(3): 99-125. 


\section{KÖZELKÉP}

Szelényi I. - Csillag T. (2015): Drifting from liberal democracy. Neo-conservative ideology of managed illiberal democratic capitalism in post-communist Europe. Intersections: East European Journal Of Society And Politics 1(1): 18-48. https://doi.org/10.17356/ieejsp.v1i1.28

Török, G. (2005): A politikai napirend. Akadémia, Budapest.

Varga M. (2018): Kampány a média tükrében. Politikai napirendkutatás a 2018-as választásról. In: Böcskei B. - Szabó A. (szerk.): Várakozások és valóságok. Parlamenti választás 2018. Napvilág, Budapest.

Watts, D. J. - Strogatz, S. H. (1998): Collective dynamics of "small-world" networks. Nature 393(3): 440-442. https://doi.org/10.1038/30918

Weaver, D. - McCombs, M. - Shaw, D. L. (2004): Agenda Settings Research: Issues, Attributes, and Influences In: Kaid, L. L.(ed.): Handbook of Political Communication Research. Routlege, New York.

\section{Online hivatkozások:}

Előd, F. (2018): Kinyírja a lakástakarékokat a kormány, index.hu 2018. október 15. https://index.hu/gazdasag/2018/10/15/lakastakarekpenztar_allami_tamogatas_megszunetetese/ (Utolsó letöltés: 2019. 08.01.)

Erdélyi, K. (2018): Orbán Viktor, a magánrepülőgép, a luxusjacht, és a Mészáros-klán - tudjuk, hol nyaraltak idén nyáron, atlatszo.hu, 2018. szeptember 24.

https://atlatszo.hu/2018/09/24/orban-viktor-a-maganrepulogep-a-luxusjacht-es-a-meszaros-klan-tudjuk-hol-nyaraltak-iden-nyaron/ (Utolsó letöltés: 2019. 08. 01.)

hvg.hu (2018): A kormányfő, vagy egy százados Flóra nevű lányát hozta haza a HM gépe Ciprusról?, hvg.hu, 2018. október 16., https://hvg.hu/itthon/20181016_ Honvedsegi_repulovel_utazhatott_haza_Orban_Rahel_Ciprusrol (Utolsó letöltés: 2019. 08. 01.)

Magyar Nemzet (2014): Megfenyegette a Hír TV-t L. Simon, mno.hu, 2014. szeptember 4., https://mno.hu/belfold/megfenyegette-a-hir-tv-t-l-simon-1246039 (Utolsó letöltés: 2019. 08.01.)

Mérték Médiaelemző Mühely (2019): Mindent beborít a Fidesz-közeli média, mertek.eu, 2019. április 25., https://mertek.eu/2019/04/25/mindent-beborit-afidesz-kozeli-media/ (Utolsó letöltés: 2019. 08. 01.)

Nagy, J. (2015): Simicska Lajos: Kinyírnak, lelőnek, elüt egy autó, 24.hu., 2015. február 6., https://24.hu/belfold/2015/02/06/simicska-lajos-kinyirnak-lelonekelut-egy-auto/ (Utolsó letöltés: 2019. 08. 01.) 


\section{KÖZELKÉP}

Siposs Z. (2015): Ez a tévé a szabadság kis szigete lett, kreativ.hu, 2015. október 7. http://kreativ.hu/media/cikk/ez_a_teve_a_szabadsag_kis_szigete_lett (Utolsó letöltés: 2019. 08. 01.) 